\title{
E Facility for Ensuring Periodic Functioning of Public Distrubution System for Rural People
}

\author{
B. VenkataSrilatha, M.M. Shanmugapriya, C. ArchanaPriya
}

\begin{abstract}
The main aim of this article is to illustrate the impact of public distribution system (PDS) in our state. The performance and problems of PDS varies regionally based on the implication of system by state governments and union territories, hence this article would give a holistic picture of obstacles in public distribution system in the state. The assessment of previous studies represents; corruption, poor quality and less quantity of entitlements, incorrect classification of below and above poverty households, bogus cards and inadequate functioning of the fair price shops are the major problems in system, therefore this article intensely discuss about the effective and benefits in PDS.
\end{abstract}

Key words: public distribution system (PDS), corruption

\section{INTRODUCTION}

Public Distribution System (PDS) is a poverty empowering program and contributes towards the social welfare of the people. Significant things like rice, wheat, sugar, light oil and such are given to the people under the PDS at reasonable expenses. PDS is an assistance to the people living underneath the gloom line. PDS is the key social welfare and antipoverty program of the Government of India. Fixed up Public Distribution System (RPDS) has been begun by the Government of India from the year 1992 in order to serve and give head things to the people living in remote, in change and slanting zones. Government showed Targeted Public Distribution System (TPDS) in the year 1997. Central Government and State Governments have been viably connected with controlling the assignments for the achievement of the PDS[1]-[5]

\section{A. Benefits of PDS to public}

The focal and state governments share the obligation of managing the PDS. While the focal government is liable for obtainment, stockpiling, transportation, and mass portion of nourishment grains, state governments hold the duty regarding appropriating the equivalent to the purchasers through the built up system of reasonable value shops (FPSs). State governments are additionally liable for operational

Revised Manuscript Received on December 30, 2019.

B. VenkataSrilatha, Assistant Professor, Department Of Science \& Humanities, Bharath Institution Of Higher Education And Research,TamilNadu,India.Email: bvsrilatha27@gmail.com

M.M. Shanmugapriya, Assistant Professor, Department Of Science \& Humanities, Bharath Institution Of Higher Education And Research TamilNadu,India.Email: priyashammu@gmail.com

C. ArchanaPriya Assistant Professor, Department Of Science \& Humanities, Bharath Institution Of Higher Education And Research TamilNadu,India.Email: Archanapriya854@gmail.com duties including distribution and distinguishing proof of families beneath the destitution line, issue of proportion cards, and supervision and observing the working of FPSs Under the PDS plot, every family underneath the destitution line is qualified for $35 \mathrm{~kg}$ of rice or wheat consistently, while a family unit over the neediness line is qualified for $15 \mathrm{~kg}$ of nourishment grain on a month to month premise.

A beneath destitution line card holder ought to be given $35 \mathrm{~kg}$ of nourishment grain and the card holder over the neediness line ought to be given $15 \mathrm{~kg}$ of nourishment grain according to the standards of PDS. Nonetheless, there are worries about the productivity of the circulation procedure.[6]-[10]

\section{OBJECTIVES OF PDS}

Objective of PDS doesn't limit the conveyance in apportioned paper. Creating accessible sufficient amounts of basic papers consistently, in places available to all, at costs moderate to everyone and insurance in more fragile area of the populace from awful winding of increasing costs in expansive range of PDS Make products accessible to customers, particularly the burdened/defenseless segments of society at reasonable costs

\section{LITERATURE REVIEW}

Amend the current lopsided characteristics between the organic market for shopper products; Check and counteract accumulating and dark advertising in fundamental wares,

\section{RESULTS \& DISCUSSION}

Endeavors was scheduled to monitor inventory manufacturing from Indian Food Enterprise stations to working sources of TNCSC Ltd Taluk and to PDS sites. For the development of Taluk godowns and shops obtained and assessed by various groups, curriculum descriptions are pursued.[11]-[15]

The Public Distribution channel General Evaluation and Control shall be conducted by the following offices: State Collectors Mutual Supply Office Co-agents / TNCSC Ltd. In their own markets, the authorities. Evaluations are expressed to go-arounds, shops as well as further enroute innovations. The structure of the all-inclusive The system of public procurement in Tamil Nadu continued with its feasible and steady operation portion applied, as it were, to the settlement of the cost of food grain in any case during the dry spell years. 
Special public distribution model The government introduced the New Public Supply system, which distributed heartbeats and pressed reinforced palmolein oil to family card holders, to detect rising heartbeat and edible oil costs in the open market RBD Palmolein fortified oil comprises vitamin A-25 IU per gram and vitamin D-2 IU per gram. Below the Specific Public Transmission system, Poop al and Palmolein Oil are provided to family card users. A total of Toor dal 20,000 MT and Palmolein oil 156 Lakh liters were obtained.Scale of supply of commoditiesThe supply of rice is free of charge under the public distribution system. Wheat, sugar and kerosene are to be sold at subsidized prices..[16]-[20]

\begin{tabular}{|c|c|c|c|}
\hline $\begin{array}{l}\text { Sl. } \\
\text { No. }\end{array}$ & $\begin{array}{l}\text { Name of the } \\
\text { commodity }\end{array}$ & Price per $\mathrm{kg}$ & Scale of supply \\
\hline 1 & Rice & Free of Cost & $\begin{array}{l}\text { All rice card users are eligible for } 5 \mathrm{~kg} \text { of } \\
\text { rice per person (including a child) permonth } \\
\text { or up-to-date (prior to NFS) entitlement, } \\
\text { whichever is greater. All AAY cards are } \\
\text { delivered } 35 \mathrm{~kg} \text { a month. }\end{array}$ \\
\hline 2 & Sugar & $\begin{array}{l}\text { Rs. } 13.50 \text { per } \mathrm{Kg} \text {. } \\
\text { for AAY cards } \\
\text { and Rs. } 25 /- \text { for } \\
\text { all other cards }\end{array}$ & $\begin{array}{l}\text { A limit of } 500 \text { grams per capita per month, } \\
\text { up to } 2 \mathrm{~kg} \text {. It's just a month. To cardholders } \\
\text { with sugar choice, } 500 \text { grams per person per } \\
\text { month plus an extra } 3 \mathrm{~kg} \text { of sugar, subject to } \\
\text { a maximum of } 5 \mathrm{~kg} \text { per month. }\end{array}$ \\
\hline 3 & Wheat & Free of Cost & $\begin{array}{l}10 \mathrm{~kg} \text { per month in Chennai City and } \\
\text { District Headquarters and } 5 \mathrm{~kg} \text { per month in } \\
\text { all other places are issued free of charge } \\
\text { instead of nice, subject to the accessibility of } \\
\text { wheat, out of the family card entitlement for } \\
\text { nice. }\end{array}$ \\
\hline 4 & Kerosene & $\begin{array}{l}\text { Rs.13.60 to } \\
\text { Rs.14.20 per litre }\end{array}$ & $\begin{array}{l}\text { Relies on the family cardholders' ownership } \\
\text { of the } \mathrm{L}_{p} \mathrm{G} \text { touch and place of residence } \\
\text { from } 3 \text { to } 15 \text { liters per family card. }\end{array}$ \\
\hline
\end{tabular}

\section{A. Agencies involved in PDS}

Collaboration, Food and Consumer Protection Department of the Government of Tamil Nadu carries out the policy for the Public Distribution System in Tamil Nadu and is under the responsibility of the Hon'ble Minister for Food and Consumer Protection and headed by the Government Secretary. The Departments are the main collaborators of PDS in Tamil Nadu.

Local Supplies and Consumer Protection Department (CS\&CPD): a Commissioner with 33 Provincial Workplaces and 302 Taluk / Zonal Workplaces.

Tamil Nadu Civil Supplies Corporation (TNCSC): is responsible for the procurement, production and distribution of basic goods under PDS and is managed by the Managing Director.

Library of Cooperative Societies (RCS): is responsible for running FPS through its useful social orders in all local areas and is managed by the Registrar assisted by the Joint Registrars in each area.

Common Supplies C.I.D. is responsible to feasible specified conditions and prohibits criminal activity against individuals involved with acts of negligence such as holding, dark displaying, storage, etc.

Meat, Consumer Affairs and Public Distribution Service: the Government of India is responsible for fixing the cost of obtaining meat grains and allocates subsidized food grains to the Government of India under the PDS.

India's food company: is a state of India organization which acquires rice, wheat and other basic products from different countries and transfers them to states according to the Ministry of Food Allocation under the PDS.[21]-[25]

\section{CONCLUSION}

Apportioning was presented in India as a nourishment control during the Second World War yet has come to remain as a perpetual element of our economy as obviously expressed in this examination. Today the PDS is proposed not exclusively to guarantee sufficient and opportune accessibility of basic items to individuals in the rustic and urban zones, especially the more fragile area. It has an overwhelmingly urban and rustic populace, a dominant part of whom are rice eaters. The administration essential target has been to build the "Reach" of the PDS and subsequently its endeavors have been coordinated towards an expansion in the quantity of PDS in order to cover most extreme populace. The focal point of strategy producers along these lines must be a how to make a PDS adequately release its commitment as a trustworthy open appropriation organization without being a lot of $h$ of a weight on the legislature and how to guarantee its endurance a development through times of excess. While finishing up, the measures like composite vendor; doorstep conveyance and upgrade of transport commission will improve the state of PDS conveyance at the front line level. Alongside that checking, watchfulness, data about privilege and openness factors from the buyers perspective ought to be fortified to improve the scope of the conveyance of fundamental products.

\section{REFERENCES}

1. Vasanthi, S. \& Rabiyathul Basariya, S. 2019, "Influence of value analysis and cross training in industry", International Journal of Engineering and Advanced Technology, vol. 8, no. 6, pp. 1810-1811.

2. Velvizhi, R., Sri Gowtham, S. \& Jeya Priya, D. 2019, "Examination of early feedbacks for effective product retailing on E-commerce websites", International Journal of Engineering and Advanced Technology, vol. 8, no. 6 Special Issue 2, pp. 703-706.

3. Anuradha, C., Pothumani, S. \& Kavitha, R. 2019, "A novel method towards E-commerce", International Journal of Engineering and Advanced Technology, vol. 8, no. 6 Special Issue 2, pp. 535-538.

4. Thomas, J. \& Rabiyathul Basariya, S. 2019, "A study on the issues of financial ratio analysis", Indian Journal of Public Health Research and Development, vol. 10, no. 3, pp. 1079-1081. 
5. Ramachandran, S. \& Rabiyathul Basariya, S. 2019, "Online marketing study on customer satisfaction and relationship", Indian Journal of Public Health Research and Development, vol. 10, no. 3, pp. 1072-1078.

6. Priya, R., Vinothini, G. \& Cor Jesu, C.D. 2019, "The mentor-protégé relationship for professional growth", Journal of Advanced Research in Dynamical and Control Systems, vol. 11, no. 9 Special Issue, pp. 1110-1119.

7. Jannifer Rani, N., Bina Pani, S. \& Nimisha, N.S. 2019, "A study on money back polices available in LIC", Journal of Advanced Research in Dynamical and Control Systems, vol. 11, no. 9 Special Issue, pp. 833-839.

8. Saillaja, V., Jhansi Rani, K. \& Catherine, R. 2019, "Global marketing management planning and organization", Journal of Advanced Research in Dynamical and Control Systems, vol. 11, no. 9 Special Issue, pp. 489-493.

9. Saillaja, V., Jhansi Rani, K. \& Catherine, R. 2019, "The new phase of marketing information system", Journal of Advanced Research in Dynamical and Control Systems, vol. 11, no. 9 Special Issue, pp. 482-488

10. Thoufiqulla \& Raju, D.V. 2019, "Perception of indian investor towards investment in mutual funds with special reference to mip funds", Journal of Advanced Research in Dynamical and Control Systems, vol. 11, no. 5, pp. 177-183.

11. Jasmine, K.R.M. \& Basariya, S.R. 2018, "A study on the customers benefits on mutual funds", International Journal of Civil Engineering and Technology, vol. 9, no. 4, pp. 45-48.

12. Vasanthi, S. \& Basariya, S.R. 2019, "Pros and cons of on the job training versus off the job training", International Journal of Scientific and Technology Research, vol. 8, no. 10, pp. 671-674.

13. Pavithra, J. \& Ganesan, M. 2016, "A study on awareness and impact of micro-financial schemes", International Journal of Applied Business and Economic Research, vol. 14, no. 8, pp. 5449-5460.

14. Pavithra, J., Dilli Babu, P. \& Ambuli, T.V. 2014, "A study on budgetary control at Maruti Service Masters, Chennai", International Journal of Applied Business and Economic Research, vol. 12, no. 2, pp. 151-161.

15. Gunaraja, T.M. \& Venkatrama Raju, D. 2018, "Determining factors of organisational climate with reference to leadership styles", International Journal of Mechanical Engineering and Technology, vol. 9, no. 9, pp. 1327-1332.

16. Gunaraja, T.M. \& Venkatrama Raju, D. 2018, "The role of job satisfaction and training of employees in determining organisational climate of a selected industry", International Journal of Civil Engineering and Technology, vol. 9, no. 8, pp. 1266-1269.

17. Aarathy, T.S. \& Raju, D.V. 2018, "Performance appraisal and its effect on employees with respect to it sector in Chennai city", International Journal of Civil Engineering and Technology, vol. 9, no. 6, pp. $1535-1538$

18. Aarathy, T.S. \& Raju, D.V. 2018, "Employee perception towards performance appraisal system in IT sector", International Journal of Mechanical Engineering and Technology, vol. 9, no. 5, pp. 131-135.

19. Porselvi, W., Jublee, D. \& Sivanesan, G. 2018, "A study on factor influencing adoption of technology and innovation in banking industry, tamilnadu, India", International Journal of Mechanical Engineering and Technology, vol. 9, no. 5, pp. 789-800.

20. Akessa, G.M. and Dhufera, A.G., 2015. Factors That Influences Students Academic Performance: A Case of Rift Valley University, Jimma, Ethiopia. Journal of Education and Practice, 6(22), pp.55-63.

21. Miller, G. and Shih, C.C., 1999. A faculty assessment of the academic rigor of on-and off-campus courses in agriculture. Journal of Agricultura Education, 40, pp.57-65.

22. Tsinidou, M., Gerogiannis, V. and Fitsilis, P., 2010. Evaluation of the factors that determine quality in higher education: an empirical study. Quality Assurance in education, 18(3), pp.227-244.

23. Farooq, M.S., Chaudhry, A.H., Shafiq, M. and Berhanu, G., 2011. Factors affecting students' quality of academic performance: a case of secondary school level. Journal of quality and technology management, 7(2), pp.1-14.

24. Fitsilis, P., Gerogiannis, V. and Anthopoulos, L., 2014. Ontologies for software project management: a review. Journal of Software Engineering and Applications, 7(13), p.1096.

25. Adams, J.D. and Jaffe, A.B., 1996. Bounding the effects of R\&D: an investigation using matched establishment-firm data(No. w5544). National bureau of economic research.

\section{AUTHORS PROFILE}

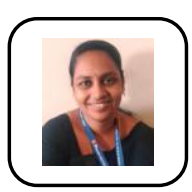

B. VenkataSrilatha, Assistant Professor, Department Of Science \& Humanities, Bharath Institution Of Higher Education And Research,TamilNadu,India

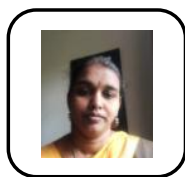

M.M. Shanmugapriya, Assistant Professor, Department Of Science \& Humanities, Bharath Institution Of Higher Education And Research TamilNadu,India.

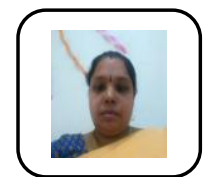

C. ArchanaPriya Assistant Professor, Department of Science \& Humanities, Bharath Institution Of Higher Education And Research TamilNadu,India 